\title{
Morphological diversity of springtails (Hexapoda: Collembola) as soil quality bioindicators in land use systems
}

\author{
Julia da Silva Machado ${ }^{1} \mathbb{B}^{,}$, Luís Carlos Iuñes Oliveira Filho ${ }^{1} \mathbb{B}$, Julio Cesar Pires Santos $\mathbb{1}_{\mathbb{D}}$,

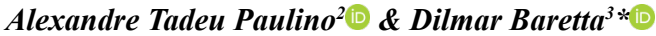 \\ ${ }^{1}$ Universidade do Estado de Santa Catarina, Centro de Ciências Agroveterinarias, Pós-Graduação em Ciência \\ do Solo, Av. Luiz de Camões, 2090, 88520-000, Lages, SC, Brasil \\ ${ }^{2}$ Universidade do Estado de Santa Catarina, Departamento de Engenharia de Alimentos e Engenharia \\ Química, Br. 282, Km 574, 89870-000, Pinhalzinho, SC, Brasil \\ ${ }^{3}$ Universidade do Estado de Santa Catarina, Departamento de Zootecnia, Rua Beloni Trombeta Zanin, \\ 680E, 89815-630, Chapecó, SC, Brasil \\ *Corresponding author: Dilmar Baretta,e-mail: dilmar.baretta@udesc.br
}

MACHADO, J.S., OLIVEIRA FILHO, L.C.I., SANTOS, J.C.P., PAULINO, A.T., BARETTA, D. Morphological diversity of springtails (Hexapoda: Collembola) as soil quality bioindicators in land use systems. Biota Neotropica. 19(1): e20180618. http://dx.doi.org/10.1590/1676-0611-BN-2018-0618

\begin{abstract}
The aim of this work was to evaluate the soil quality of native forest, eucalyptus plantations, pasture, integrated crop-livestock, and no-tillage systems, correlating the morphological diversity of springtails with physical and chemical soil properties. Springtail samples were captured from soils of the southern plateau of the State of Santa Catarina in Brazil, during winter and summer, by using Pitfall traps, using a $3 \times 3$ point grid. The morphotyping of springtails consisted of the observation of five traits and for each one a partial value of the ecomorphological index was assigned to obtain the modified Soil Quality Index. A correlation of the morphotype abundance and diversity with physical (soil moisture, bulk density, biopores, microporosity, and macroporosity) and chemical ( $\mathrm{pH}$ in water, calcium/magnesium ratio and total organic carbon content) soil properties was studied, describing all results by variance and multivariate analyses. The springtail abundance and diversity were influenced by the different land use systems. Higher soil quality index was determined in native forest followed by eucalyptus plantations, pasture, no-tillage system and integrated crop-livestock, in the winter. Moreover, higher soil quality index was found in native forest followed by integrated crop-livestock, eucalyptus plantations, no-tillage system and pasture, in the summer. Therefore, the quality index of a soil can be evaluated by the springtail morphological traits in correlation with the physical and chemical properties such as calcium/magnesium ratio, total organic carbon contents, biopores, macroporosity, microporosity, soil moisture, bulky density and $\mathrm{pH}$.
\end{abstract}

Keywords: Biodiversity; Morphotype; Soil Mesofauna; Soil Quality Index.

\section{Diversidade morfológica de colêmbolos (Hexapoda: Collembola) como bioindicadora de qualidade do solo em sistemas de uso}

Resumo: O objetivo deste trabalho foi avaliar a qualidade do solo de florestas nativas, reflorestamento de eucalipto, pastagem, sistemas de integração lavoura-pecuária e plantio direto, correlacionando a diversidade morfológica de colêmbolos com propriedades físicas e químicas do solo. Amostras de colêmbolos foram coletadas de solos do planalto sul do Estado de Santa Catarina no Brasil, durante o inverno e o verão, usando armadilhas de queda, em grade amostral de $3 \times 3$. A morfotipagem dos colêmbolos consistiu na observação de cinco características e para cada uma foi atribuído um valor parcial do índice eco-morfológico para a obtenção do Índice de Qualidade do Solo modificado. As avaliações foram da abundância e diversidade de morfotipos e de atributos físicos (umidade do solo, densidade do solo, bioporos, microporosidade e macroporosidade) e químicos do solo ( $\mathrm{pH}$ em água, relação cálcio/magnésio e carbono orgânico total), descrevendo os resultados por análises de variância e multivariada. A abundância e a diversidade de colêmbolos foram influenciadas pelos diferentes sistemas de uso do solo. Maior índice de qualidade do solo foi determinado em floresta nativa seguida de reflorestamento de eucalipto, pastagem, plantio direto e integração lavoura-pecuária, no inverno. Além disso, encontrou-se maior índice de qualidade do solo em floresta nativa seguida de integração lavoura-pecuária, reflorestamento de eucalipto, plantio direto e pastagem, no verão. Portanto, o índice de qualidade do solo pode ser avaliado pelas características morfológicas de colêmbolos em correlação com as propriedades físicas e químicas, como razão cálcio/magnésio, teores de carbono orgânico total, bioporos, macroporosidade, microporosidade, umidade do solo, densidade do solo e $\mathrm{pH}$.

Palavras-chave: Biodiversidade; Morfotipos; Mesofauna do Solo; Índice de Qualidade do Solo. 


\section{Introduction}

The different land use systems alter the edaphic organism natural habitats, decreasing their abundance and biodiversity (Huerta \& van der Wal 2012, Rosa et al. 2015, Keesstra et al. 2016). The edaphic organism communities in soils are important for the ecosystem due to their ecological functions and relations with plants, soils, animals, and water (Bardgett \& Van Der Putten 2014). Edaphic organisms are also very important for understanding the dynamic of certain crop production systems, in addition, to be used as soil environmental quality natural bioindicators (Lavelle et al. 2006, Lima et al. 2013, Baretta et al. 2014).

Springtails (Hexapoda: Collembola) are an important and abundant soil microarthropod as interacts with ecosystem physiochemical processes, decomposing and mineralizing significant organic matter amount by the litterfall fragmentation and fecal production (Madej et al. 2011, Ruggiero et al. 2015). Moreover, the presence of springtails in soil is used for predicting and controlling primary decomposer actions such as bacteria and fungi and secondary decomposer actions such as nematodes and protozoa (Filser 2002, Petersen 2002, Jeffery et al. 2010, Paul et al. 2011, Chang et al. 2013). Springtails are frequently abundant and sensitive to changes in the physical and chemical soil properties and natural micro-habitat characteristics after agricultural and forestry activities. This sensitivity can be used for indicating pollution levels in different land use systems (Eaton et al. 2004, Larsen et al. 2004, Sousa et al. 2006, Baretta et al. 2008, Rieff et al. 2014). In this sense, different springtails communities have been widely used as soil environmental quality bioindicators in studies of environmental pollution related with the land use systems (Parisi et al. 2005, Ponge et al. 2006, Oliveira Filho et al. 2016, Winck et al. 2017, Santos et al. 2018). The springtails communities are divided in edaphic, hemiedaphic and epigeic organisms. Edaphic and epigeic organisms are generally found in soils that contain litterfall and deeper layer, respectively, whereas hemiedaphic organisms are generally found in both surface and deeper layers as an intermediate vertical distribution (Gisin 1943, Petersen 2002, Querner et al. 2013, Oliveira Filho \& Baretta 2016). This vertical stratification is important to predict the soil environmental quality level since the decrease of litterfall affects much more the epigeic organisms than edaphic organisms.

Different springtails morphotypes in a region can be correlated with the physical and chemical soil properties and different land use systems. Moreover, it can be used to predict the relations between springtails and ecosystem (Oliveira Filho et al. 2016). The morphological classification of different springtails species in a region can be used for fast evaluation of this biodiversity compared to classification by the traditional taxonomy method. Moreover, initial springtails biodiversity evaluation by morphotype classification covers much more soils and areas than the traditional taxonomy method (Reis et al. 2016). For example, a sustainable land use system in Italy has been defined by the presence of different microarthropod groups in soil, using the organism biodiversity and speciation indexes as parameters for predicting the soil environmental quality (Parisi 2001, 2005, Gardi et al. 2002, Menta et al. 2018a, 2018b). The greater the soil environmental quality, higher the number of microarthropods adapted to this soil, indicating lower environmental pollution indexes. The different springtails and Coleoptera morphotype classifications in soils have been used as environmental tools for studying sustainable land use systems (Vandewalle et al. 2010, Oliveira Filho et al. 2016, Reis et al. 2016, Silva et al. 2016, Pompeo et al. 2017, Santos et al. 2018). In this case, the soil use was correlated with the organism morphotypes and soil biological quality index (Qualità Biologica del Suelo - QBS).

The aim of this work was to study the springtails community structure in different land use systems by measuring the abundance, morphological diversity and QBS index, correlating these informations with physical and chemical soil properties. The correlation between springtails morphotype diversity and physical and chemical properties explained the soil vertical stratification and its environmental quality. Evaluating the environmental quality of soils by using morphological classifications of edaphic, hemiedaphic and epigeic organism groups is not common around the world. Therefore, this new methodology could be an effective tool for defining sustainable land intense use systems by determining the significant correlations between springtails morphological diversity and physical and chemical soil properties in order to avoid the environmental pollution.

\section{Material and Methods}

\section{Description of the study site}

The experimental studies were accomplished in the southern plateau of the state of Santa Catarina in Brazil, including the counties of Campo Belo do Sul and Lages with Nitisol (Nitossolo Bruno) and Otacílio Costa with Humic Cambisol (Cambissolo Húmico) (WRB 2014; Brazilian classification: Embrapa, 2013). These regions were chosen due to the geographical characteristics of tepid climates with temperatures ranging from 18.0 to $22.0 \pm 1.0{ }^{\circ} \mathrm{C}$ according to the Köppen climate classification, $\mathrm{Cfb}$ (Alvares et al. 2013). Five land use systems (LUS) were chosen in each region with the aim of establishing the anthropological action gradients in native forest (NF), eucalyptus plantations (EP), pasture (PA), integrated crop-livestock (ICL), and no-tillage (NT) systems. Environmental and soil management characteristics in the sampling regions in each county of the southern plateau of the state of Santa Catarina are displayed in Table 1.

\section{Soil samples}

Soil samples were collected in the months of July (winter) and January (summer). Samples were collected using a $3 \times 3$ point grid, with sampling points at a distance of $30 \mathrm{~m}$ from each other and surrounded by a 20-m border, covering 1 ha for each LUS (Bartz et al. 2014b, Rosa et al. 2015). Five soil samples were collected in each sampling point at depths of 0 to $20 \mathrm{~cm}$ due to the high amount of springtails in this stratification, totaling 150 samples.

\section{Springtails samples}

The springtails samples were collected by using $500 \mathrm{~mL}$ pitfall traps with $8 \mathrm{~cm}$ cylindrical diameters. These traps containing $200 \mathrm{~mL}$ of $3: 1$ detergent aqueous solution were put on the soil surface for $72 \mathrm{~h}$ (Bartz et al. 2014a). Next, the traps were removed from the soil and the springtails samples separated for fixation in $99.5 \%$ ethanol. Specimens of this survey are housed at the Collection of the Centro de Educação Superior do Oeste, Santa Catarina State University. 
Springtails in land use systems

Table 1. Environmental and soil management characteristics in the sampling regions in each county of the southern plateau of the state of Santa Catarina.

\begin{tabular}{|c|c|c|c|c|c|}
\hline Attributes & Native Forest (NF) & $\begin{array}{c}\text { Eucalyptus } \\
\text { plantations (EP) }\end{array}$ & Pasture (PA) & $\begin{array}{c}\text { Integrated } \\
\text { crop-livestock (ICL) }\end{array}$ & No-Tillage (NT) \\
\hline \multicolumn{6}{|c|}{ County of Campo Belo do Sul } \\
\hline Altitude (m) & 1016 & 989 & 1004 & 947 & 923 \\
\hline \multirow[t]{2}{*}{ UTM (J22 zone) } & 533895.8 & 534356.2195 & 534167.5 & 534356.22 & 534167.46 \\
\hline & 6915778.881 & 6915002.151 & 6917279.118 & 6915002.2 & 6917279.1 \\
\hline Size (ha) & 5 & 1 & 6.9 & 4 & 1.1 \\
\hline $\begin{array}{l}\text { Vegetation and } \\
\text { Management }\end{array}$ & $\begin{array}{l}\text { Mixed ombrophilous } \\
\text { forest. Secondary } \\
\text { forest. Entrance of } \\
\text { people and cattle. }\end{array}$ & $\begin{array}{l}\text { Native grassland } \\
\text { previously. Entrance } \\
\text { of people and cattle. }\end{array}$ & $\begin{array}{l}\text { Native grass. } \\
\text { Controled burning } \\
\text { every two years }\end{array}$ & $\begin{array}{l}\text { No-tillage with crop } \\
\text { rotation (soybean, } \\
\text { corn, wheat, oat). } \\
\text { Use of herbicides, } \\
\text { insecticides, and } \\
\text { fungicides. }\end{array}$ & $\begin{array}{l}\text { No-tillage (soybean, } \\
\text { corn, wheat and } \\
\text { fallow). Use } \\
\text { of herbicides, } \\
\text { insecticides, and } \\
\text { fungicides. }\end{array}$ \\
\hline UTM (J22 zone) & 6924955.115 & 6925346.417 & 6925122.656 & 6925346.4 & 6925122.7 \\
\hline Size (ha) & 3.5 & 2.8 & 7.6 & 14 & 4 \\
\hline Age (years) & - & 7 & 15 & 10 & 7 \\
\hline $\begin{array}{l}\text { Vegetation and } \\
\text { Management }\end{array}$ & $\begin{array}{l}\text { Mixed ombrophilous } \\
\text { forest. Secondary } \\
\text { forest. Entrance of } \\
\text { cattle. }\end{array}$ & Entrance of cattle. & Native grass & $\begin{array}{l}\text { No-tillage with crop } \\
\text { rotation (soybean, } \\
\text { corn, oat, ryegrass). } \\
\text { Use of herbicides, } \\
\text { insecticides } \\
\text { (physiological), and } \\
\text { fungicides. }\end{array}$ & $\begin{array}{l}\text { No-tillage (soybean, } \\
\text { corn, wheat). Use of } \\
\text { herbicides, insecticides } \\
\text { (physiological), and } \\
\text { fungicides. }\end{array}$ \\
\hline $\begin{array}{l}\text { Vegetation and } \\
\text { Management }\end{array}$ & $\begin{array}{l}\text { Mixed ombrophilous } \\
\text { forest. Secondary } \\
\text { forest. Entrance of } \\
\text { cattle. }\end{array}$ & - & $\begin{array}{l}\text { Native grass. Annual } \\
\text { controlled burning. }\end{array}$ & $\begin{array}{l}\text { No-tillage with crop } \\
\text { rotation (soybean, } \\
\text { corn, oat, ryegrass). } \\
\text { Use of herbicides, } \\
\text { insecticides, and } \\
\text { fungicides. }\end{array}$ & $\begin{array}{l}\text { No-tillage (soybean, } \\
\text { corn, oat, ryegrass). } \\
\text { Use of herbicides, } \\
\text { insecticides, and } \\
\text { fungicides. }\end{array}$ \\
\hline
\end{tabular}

\section{Morphological characterization}

The collected springtails samples were counted and distributed according to their morphotypes by using a stereoscopic microscopic with magnifications from 0 to 50 times. Each springtails morphotype was identified by determining the eco-morphological index as described by Parisi $(2001,2005)$. The springtails adaptations and codifications were studied according to the methodologies described by Vandewalle et al. (2010), Parisi (2001, 2005), Oliveira Filho et al. (2016), Reis et al. (2016), Silva et al. (2016) and Santos et al. (2018). In this case, five traits were evaluated for each springtail including antennal length, size of furca, presence of ocelli (the authors mentioned above used the presence or absence, regardless of the number, which makes the evaluation faster), pigmentation, and presence of hairs and/or scales along the body (considered only macro hairs/scales). Each trait was identified by the eco-morphological index (EMI) value as displayed in Table 2. The EMI final values varied from 0 to 20 which were used for describing the springtails morphotypes (Table 3). The EMI value is important to separate the springtails samples according to adaptation degree in soil. In this case, the higher the EMI values the lower the capacities of morphotype dispersions, facilitating their adaptation on the soil profile. The springtails morphotypes were classified as edaphic, hemiedaphic and epigeic depending on the total EMI values. Total EMI values ranging from 14 to 20 indicated the presence of edaphic organisms due to lower dispersion and better adaptation in soil. For hemiedaphic organisms, the total EMI values ranged from 8 to 12 and for epigeic organisms, the total EMI values ranged from 0 to 6 . 
Table 2. Springtails morphological characteristics and eco-morphological index (EMI) values

\begin{tabular}{lcc}
\hline $\begin{array}{l}\text { Characteristics } \\
\text { (trait) }\end{array}$ & Codification & EMI \\
\hline \multirow{2}{*}{ Ocelli } & Present & 0 \\
& Absent & 4 \\
\multirow{3}{*}{ Antenna length } & Antenna length $>$ body length & 0 \\
& Antenna length $>0.5 x$ body length & 2 \\
& Antenna length $<0.5 x$ body length & 4 \\
Furca & Present (fully developed) & 0 \\
& Present but reduced/short & 2 \\
Hairs and/or Scales & Absent & 4 \\
& Present & 0 \\
Pigmentation & Absent & 4 \\
& Colored but not uniformly pigmented & 2 \\
& Absent (white color or transparent) & 4 \\
\hline
\end{tabular}

\section{Soil biological quality index}

In the present study, an adaptation was used to calculate the QBS index (QBS-adapt; Parisi 2001, 2005), because it is a specific study for the Collembola group. The QBS-adapt tries to cover all the morphotypes found in an area and does not consider only the edaphic ones (higher EMI). In QBS-adapt, the abundance of springtails of a determined morphotype is multiplied by its respective final value of EMI, after which the sum of this multiplication is added to all the morphotypes found in a given area. In this way, it is possible to obtain more reliable information related with the adaptations of springtails in the environment and on the conditions of soil quality, since all the individuals that occur in a place are considered.

\section{Soil properties}

The physical and chemical properties collected from NF, EP, PA, ICL, and NT were determined by using fifteen samples of different points of each soil (Table 4). All fifteen samples from each soil were homogenized with the aim of obtaining a representative mixed sample for the determination of $\mathrm{pH}$ in water, available $\mathrm{Ca}^{2+}$ and $\mathrm{Mg}^{2+}$ and total organic carbon contents according to methodologies described by Tedesco et al. (1995). Soil moisture and bulk density, biopores, microporosity, and macroporosity were determined by using samples with preserved structures collected in a $5.0 \mathrm{~cm}$ diameter and $5.0 \mathrm{~cm}$ height steel cylinder according to procedures described by Embrapa (2011).

\section{Statistical analyses}

The abundance, richness, and Margalef Index were calculated by using software PAST 2.17c (Hammer et al. 2001). Data (without outliers) were transformed $(\sqrt{ } \mathrm{x}+1)$ to comply with the requirements of analysis of variance (ANOVA; normal distribution and homoscedasticity of error variances). The normality of data was checked with Kolmogorov-Smirnov's and homogeneity of variances was tested using Bartlett's test. Analysis of variance was calculated by using software
Statistic 7.0 (StatSoft 2004) with the aim of comparing the organism abundances in traps, total abundances, and land use system indexes. All analyses were accomplished for soil samples collected from NF, EP, PA, ICL, and NT considering as reliable replicates those calculated by multiplying triplicate samples by number of municipalities. All results were presented as a mean \pm standard deviation, comparing these media by using Newman Keuls test $(\mathrm{p}<0.05)$ (Keuls 1952). Means presented in the text and figures were calculated using non-transformed data $( \pm$ standard deviation). Similarity percentages (SIMPER) analyses were run to determine dissimilarity between treatments and morphotypes contributions to the observed collembolan assemblage structure under the different LUS, using PRIMER version 5.2.6 (Clarke, 1993).

Morphotype abundances and physical and chemical soil properties were also determined by principal component analysis (PCA) by using software Canoco 4.0 (Ter Braak \& Šmilauer 2002). Morphotype abundances were studied as response variables and physical and chemical soil properties as explanatory environmental variables. Forward selection was applied for successive redundant analyses by using Monte-Carlo test $(\mathrm{p}<0.002)$, removing information that has presented collinearity and using variables that explained the variations of data $(\mathrm{p} \leq 0.05)$. Therefore, the significant explanatory environmental variables from redundant tests were used for plotting the PCA graphics with the aim of explaining all changes observed for the springtails morphotypes.

\section{Results}

\section{Abundance, richness, and diversity of springtails in the land use systems}

A total of 21,151 individuals were collected and morphotyped, of which 12,259 individuals were collected in the summer and 8,892 individuals in the winter. The abundances of springtails in the summer were higher in the NF followed by EP, NT, PA, and ICL (Table 5). Moreover, these abundances in the winter were higher in the NF followed by ICL, NT, EP, and PA (Table 5). Forty-five springtails morphotypes were determined (Table 3) including E8 with 7,997 individuals, $\mathrm{H} 4$ with 6,396 individuals and $\mathrm{E} 3$ with 2,951 individuals.

The mean richness was not significantly different among the land use systems during the winter, however was significantly different during the summer. There were not common standards for the biodiversity in the different land use systems. The diversity index in the winter was not significantly different by using Margalef test.

The diversity index based on the Margalef test during the summer was significantly different for soils from areas of PA was 1.70 compared to the richness of morphotypes in NF. The presence of certain morphotypes (E3, E8, E20, H4, H16, H24, H25, H37, H46, H50), indicated by SIMPER analysis, showed that were responsible for $50.5 \%$ of the dissimilarity between NF and PA; $50.7 \%$ between EP and PA; $42.1 \%$ between PA and ICL; $42.9 \%$ PA and NT; $48.6 \%$ between NF and EP; $46.3 \%$ between NF and ICL; $47.1 \%$ between EP and ICL; $45.5 \%$ between NF and NT; $45.9 \%$ between EP and NT; $30.2 \%$ between ICL and NT. Thus, these morphotypes may come to be considered as the most important in these LUS. 
Table 3. Standard morphological classification of collembola

\begin{tabular}{|c|c|c|c|c|c|c|c|}
\hline \multicolumn{5}{|c|}{ Partial eco-morphological index values } & \multirow{3}{*}{$\begin{array}{l}\text { EMI } \\
\text { Final }\end{array}$} & \multirow{3}{*}{$\begin{array}{c}\text { Eco-morphological } \\
\text { groups }\end{array}$} & \multirow{3}{*}{$\begin{array}{c}\text { Sampled } \\
\text { morphotypes }\end{array}$} \\
\hline Ocelli & Antenna length & Furca & Hairs/scales & Pigmentation & & & \\
\hline $0-4$ & $0-2-4$ & $0-2-4$ & $0-4$ & $0-2-4$ & & & \\
\hline 4 & 4 & 4 & 4 & 2 & 18 & Edaphic & $\mathrm{E} 2$ \\
\hline 4 & 4 & 2 & 4 & 4 & 18 & Edaphic & E3 \\
\hline 4 & 4 & 2 & 4 & 2 & 16 & Edaphic & E7 \\
\hline 4 & 4 & 0 & 4 & 4 & 16 & Edaphic & E8 \\
\hline 0 & 4 & 4 & 4 & 4 & 16 & Edaphic & E12 \\
\hline 4 & 4 & 2 & 0 & 4 & 14 & Edaphic & E15 \\
\hline 4 & 2 & 0 & 4 & 4 & 14 & Edaphic & E20 \\
\hline 0 & 4 & 4 & 4 & 2 & 14 & Edaphic & E23 \\
\hline 0 & 4 & 2 & 4 & 4 & 14 & Edaphic & E24 \\
\hline 0 & 2 & 4 & 4 & 4 & 14 & Edaphic & E25 \\
\hline 4 & 4 & 2 & 0 & 2 & 12 & Hemiedaphic & $\mathrm{H} 2$ \\
\hline 4 & 4 & 0 & 4 & 0 & 12 & Hemiedaphic & $\mathrm{H} 3$ \\
\hline 4 & 4 & 0 & 0 & 4 & 12 & Hemiedaphic & $\mathrm{H} 4$ \\
\hline 4 & 2 & 0 & 4 & 2 & 12 & Hemiedaphic & $\mathrm{H} 8$ \\
\hline 4 & 0 & 0 & 4 & 4 & 12 & Hemiedaphic & $\mathrm{H} 12$ \\
\hline 4 & 0 & 0 & 4 & 2 & 10 & Hemiedaphic & $\mathrm{H} 29$ \\
\hline 0 & 4 & 2 & 0 & 4 & 10 & Hemiedaphic & H32 \\
\hline 0 & 4 & 0 & 4 & 2 & 10 & Hemiedaphic & H33 \\
\hline 0 & 2 & 2 & 4 & 2 & 10 & Hemiedaphic & H36 \\
\hline 0 & 2 & 0 & 4 & 4 & 10 & Hemiedaphic & $\mathrm{H} 37$ \\
\hline 4 & 2 & 0 & 0 & 2 & 8 & Hemiedaphic & $\mathrm{H} 42$ \\
\hline 4 & 0 & 0 & 0 & 4 & 8 & Hemiedaphic & $\mathrm{H} 46$ \\
\hline 0 & 4 & 2 & 0 & 2 & 8 & Hemiedaphic & H48 \\
\hline 0 & 4 & 0 & 4 & 0 & 8 & Hemiedaphic & H49 \\
\hline 0 & 4 & 0 & 0 & 4 & 8 & Hemiedaphic & $\mathrm{H} 50$ \\
\hline 0 & 2 & 4 & 0 & 2 & 8 & Hemiedaphic & H51 \\
\hline 0 & 2 & 0 & 4 & 2 & 8 & Hemiedaphic & $\mathrm{H} 54$ \\
\hline 0 & 0 & 0 & 4 & 4 & 8 & Hemiedaphic & H58 \\
\hline 0 & 4 & 0 & 0 & 2 & 6 & Epigeic & EP5 \\
\hline 0 & 2 & 0 & 0 & 4 & 6 & Epigeic & EP9 \\
\hline 0 & 0 & 0 & 4 & 2 & 6 & Epigeic & EP13 \\
\hline 0 & 2 & 0 & 0 & 2 & 4 & Epigeic & EP17 \\
\hline 0 & 0 & 0 & 0 & 4 & 4 & Epigeic & EP21 \\
\hline
\end{tabular}


Machado, J.S. et al.

Table 4. Soil properties in native forest (NF), eucalyptus plantations (EP), pasture (PA), integrated crop-livestock (ICL), and no-tillage (NT) systems in the southern plateau of the state of Santa Catarina during winter and summer.

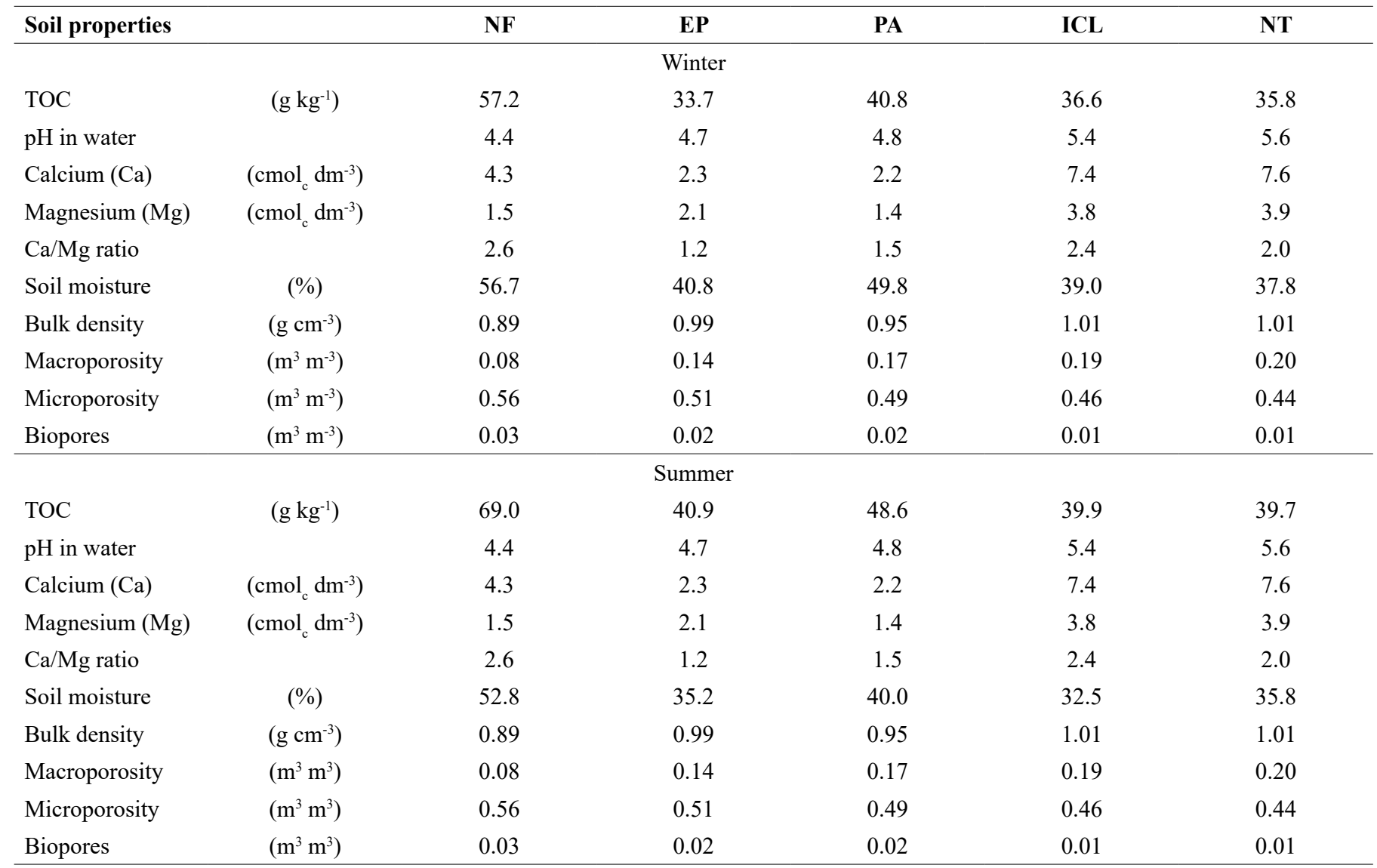

$\mathrm{TOC}=$ Total organic carbon; Calcium/Magnesium ratio in soils.

Table 5. Abundance, richness, diversity of springtails morphotypes (mean \pm standard deviation), and soil biological quality-adapt (QBS-adapt) in native forest (NF), eucalyptus plantations (EP), pasture (PA), integrated crop-livestock (ICL), and no-tillage (NT) systems of the southern plateau of the state of Santa Catarina ( $\mathrm{n}=15$ ).

\begin{tabular}{|c|c|c|c|c|}
\hline LUS & $\begin{array}{c}\text { Abundance } \\
\left(\text { Organism trap }^{-1}\right)\end{array}$ & $\begin{array}{c}\text { Richness } \\
\text { (Number of morphotypes) }\end{array}$ & Margalef Index & QBS-adap \\
\hline \multicolumn{5}{|c|}{ Winter } \\
\hline $\mathrm{EP}$ & $145 \mathrm{ab}( \pm 40)$ & $8( \pm 0.7)$ & $1.54( \pm 0.5)$ & 33,294 \\
\hline $\mathrm{PA}$ & $81 \mathrm{~b}( \pm 20)$ & $9( \pm 1.2)$ & $1.96( \pm 0.8)$ & 19,320 \\
\hline \multicolumn{5}{|c|}{ Summer } \\
\hline NF & $307 \mathrm{a}( \pm 82)$ & $8 \mathrm{a}( \pm 0.8)$ & $1.22 \mathrm{~b}( \pm 0.1)$ & 66,442 \\
\hline EP & $107 \mathrm{~b}( \pm 38)$ & $6 \mathrm{ab}( \pm 07)$ & $1.23 \mathrm{~b}( \pm 0.1)$ & 25,316 \\
\hline PA & $72 b( \pm 25)$ & $7 \mathrm{a}( \pm 0.7)$ & $1.70 \mathrm{a}( \pm 0.2)$ & 15,690 \\
\hline
\end{tabular}

${ }^{n s}$ without significant difference. 
Springtails in land use systems

\section{Analysis of springtails community composition}

The springtails morphotype abundances were applied as response variables and physical and chemical soil properties as explanatory environmental variables. Based on multivariate analysis, different land use systems were identified with NF different of PA, EP, NT, and ICL. The morphotype abundances and diversities were mainly related with the physical and chemical soil properties, changing with the alterations of porosity, soil moisture, acidity and fertility of the soils from the land use systems.

The variability of the experimental data was explained by the first $(21.0 \%)$ and second $(16.9 \%)$ principal component during the winter (Figure 1A). Higher morphotype abundances and distributions were observed in NF compared to different eco-morphological groups. Moreover, significant correlations of hemiedaphic morphotypes were observed in the ICL and NT. A correlation among the calcium/magnesium ratio, total organic carbon, biopores, microporosity, and soil moisture contributed for the explanation of the morphotype abundances in NF whereas macroporosity explained the association among morphotypes in ICL and NT. The microporosity was used to explain the morphotype abundances in PA and EP.

The variability of the experimental data was explained by the first $(22.1 \%)$ and second (17.7\%) principal component during the summer (Figure 1B). Similar results were obtained for the abundances, distributions, and adaptations of morphotypes in NF during winter and summer. Higher abundances of epigeic organisms were determined in NT. However, significant correlations between hemiedaphic organisms were similarly observed in ICL during the summer. Important correlations were also observed during the summer between springtails and physical and chemical soil properties in PA and EP. Total carbon content and microporosity contributed for the explanation of the morphotype abundances in NF whereas $\mathrm{pH}$, biopores, and bulk density explained the morphotype association among ICL and NT.

\section{Soil biological quality index}

The soil biological quality-adapt (QBS-adapt) index is used to define the quality of a specific soil based on the microarthropod abundance and sensibility (Parisi et al. 2005). Higher QBS-adapt index was determined in the winter for soils with less anthropological actions. The higher the QBS-adapt index the more complex is the land use system. High QBS-adapt index was determined in soils from NF at both seasons due mainly to the increase of the organic matter contents on the soil surface which are food sources for different springtails morphotypes (Table 5).

\section{Discussion}

\section{Community composition of springtails}

The intense land use systems and landscape differences influenced the abundance and diversity of springtails morphotypes. In this sense, the springtails community structure can be used for identify changes in the land use systems (Loring et al. 1981, Paul et al. 2011, Chang et al. 2013). The abundance and diversity of springtails in land use systems are also altered due to region fauna, soil density, microorganism activities, climate conditions, micro-habitat structures, agricultural practices, physiochemical properties of soils such as soil type and structure, pH and organic matter content (Hopkin 1997, Pflug \& Wolters 2002,
(A)

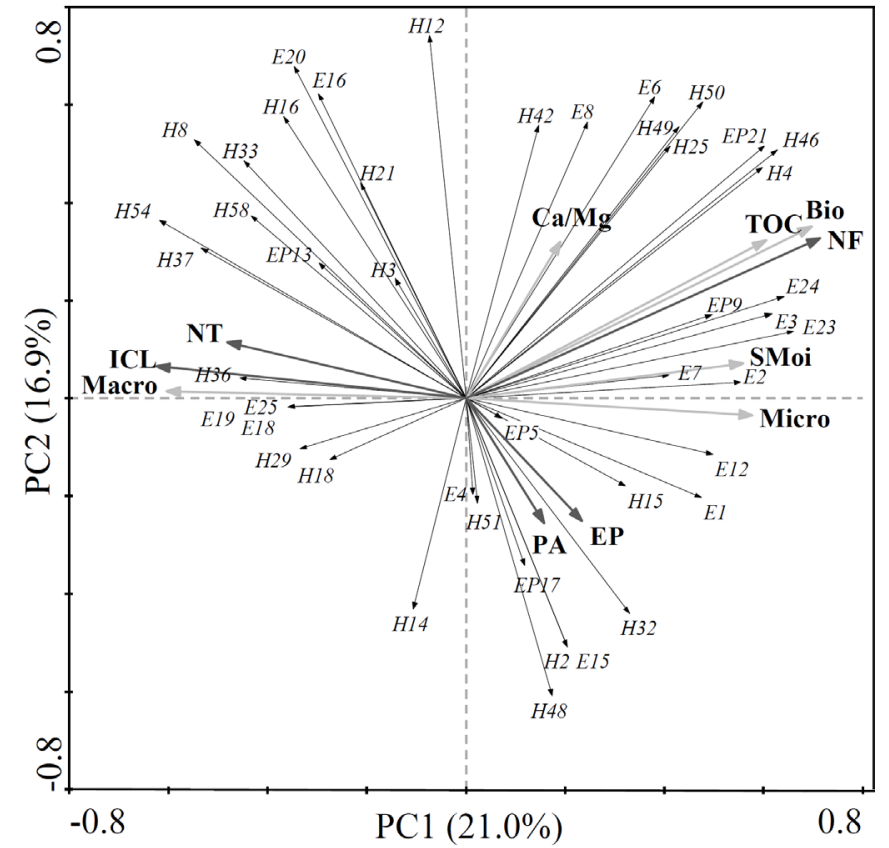

(B)

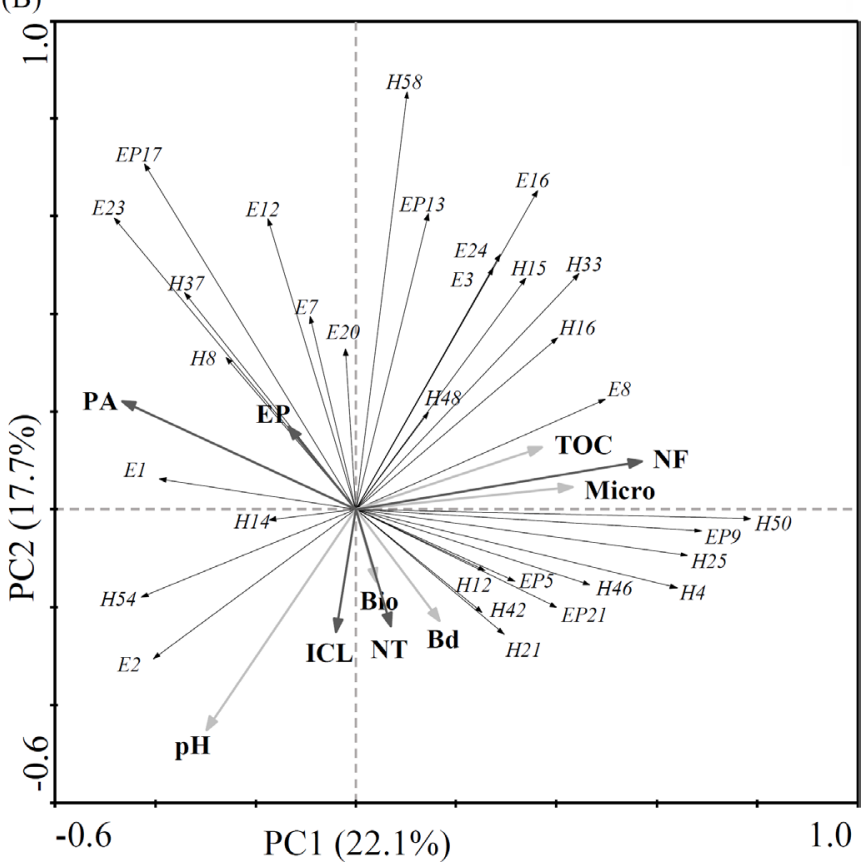

Figure 1. Principal component analysis (PCA) for springtails morphotypes and physiochemical attributes in native forest (NF), eucalyptus plantations (EP), pasture (PA), integrated crop-livestock (ICL) and no-tillage (NT) systems during winter (A) and summer (B) for land use systems in the southern plateau of the state of Santa Catarina. E: Edaphic; H: Hemiedaphic; EP: Epigeic. Bio: Biopores; Macro: macroporosity; Micro: microporosity; Bd: Bulk density; SMoi: Soil moisture; TOC: Total organic carbon; $\mathrm{Ca} / \mathrm{Mg}$ : Calcium/Magnesium ratio; $\mathrm{pH}$ : acidity.

Schröder 2008, Roźen et al. 2010). Higher springtails abundances were determined in the land use systems without anthropological actions and soil management due to the better ecological equilibrium. It increases the food sources for organisms by the significant litterfall deposition and root exudation on/in soils (Bandyopadhyaya et al. 2002, Paul et al. 2011). 
The similar values of richness and Margalef index during the winter can be associated to the climate conditions in the southern plateau of the state of Santa Catarina (Alvares et al. 2013) and different soil management processes that contain vegetal permanent covers (Rosa et al. 2015). According to Sousa et al. (2006), pasture areas are more important for the development and growth of springtails than agricultural areas due to anthropological actions during the planting of different crops. Accordingly, lower abundance and richness of springtails were experimentally determined for agricultural soils from the southern plateau of the state of Santa Catarina (Santos et al. 2018), indicating that intense land use systems increase the impacts on the environment. However, the springtails biodiversity increases in intense agro-ecosystems containing perennial pastures without using agrochemicals (Gardi et al. 2002).

Higher values for the Margalef index were determined in regions containing pastures, indicating higher springtails diversity compared to others areas as observed elsewhere (Santos et al. 2018). In general, the Margalef index were lower than 2.0 in the southern plateau of the state of Santa Catarina as observed in the east plateau studied by Santos et al. (2018), indicating low organism diversity and potential environmental impact. On the contrary, the Margalef index and total richness of springtails in the southwest plateau were higher than those determined in the east plateau, demonstrating that the springtails morphotype diversities can intrinsically or naturally be lower in all study areas in the southern plateau (Santos et al. 2018).

\section{Community distribution of springtails and their relationships with soil properties}

The principal component analysis was efficient for explaining and describing environmental variables and the springtails presence in each land use system. Lower soil porosity influenced the springtails abundances in soils for all land use systems. There is a close inter-correlation between springtails, soil macroporosity (pore sizes higher than $0.08 \mathrm{~mm}$ ) and soil biopores (pore sizes higher than 1.0 $\mathrm{mm}$ ) since these organisms are not morphologically capable of either digging tunnels or galleries into soils (Hopkin 1997, Beylich et al. 2010). Therefore, survival rates of springtails morphotypes depend on their body diameters and soil porosities in land use systems (Larsen et al. 2004). A decrease in the springtails abundance was also observed with the decrease of the soil surface macroporosity in NT and ICL due to lower organic matter concentration which is responsible by the channel formation in soils from land use systems (Bot \& Benites 2005, Cavalieri et al. 2009, He et al. 2011).

A significant correlation between the calcium/magnesium ratio and total organic carbon contents in NF was determined as observed elsewhere (Chagnon et al. 2000, 2001, Cassagne et al. 2003, Oliveira Filho et al. 2016). Another correlation between eco-morphological groups and total organic carbon contents should be occurring which favor the growing of springtails morphotypes that contain fungivorous habits (Scheu \& Folger 2004, Sawahata 2006). Some springtails morphotypes can act as immobilizers of nutrients in either soils or plants during the planting of different crops (Eaton et al. 2004). The immobilization of nutrients in either soils or plants also increases the springtails growth rates (Ineson et al. 1982, Filser 2002, Culliney 2013).
Main correlations were determined among $\mathrm{pH}$, biopores, and bulk density with ICL and NT. The limestone application in agricultural soils increases the $\mathrm{pH}$ and nutrient bioavailability, generating a multivariate statistic correlation as experimentally observed (Frazão et al. 2008). Changes in the soil $\mathrm{pH}$ and bulk density alter the springtails communities (Chagnon et al. 2000, 2001, Ponge 2000), although these soil properties did not influence the edaphic organism communities and root growth in the crops of the different studied land use systems. This was attributed to the soil biopores and structure in the depths ranging from 0.00 to $20.0 \mathrm{~cm}$. A correlation between total organic carbon contents and NF was observed in the two seasons as indicated in Figures 1A and 1B due to the absence of anthropological actions in this land use system. This was not observed in the other land use systems due to soil enrichment processes that change the total organic contents (Paustian et al. 1997). Depending on the land use system, it can be determined by a decrease in the organic matter decomposition rates in soil (Jastrow et al. 1996, Six et al. 1998, Ogle et al. 2005) which increase with the presence of springtails morphotypes (Yang et al. 2012, Verma et al. 2014).

\section{Adapted Soil Biological Quality Index (QBS-adapt)}

Higher QBS-adapt index is associated with wooded regions which improve the environmental conditions and increase the microarthropod diversities (Madej et al. 2011). The QBS-adapt index determined during the winter indicated higher intensification in the land use systems, confirming that the more complex and structured the system the higher the amount and diversity of springtails morphotypes. It indicates a higher soil quality. Lands mixed by plow tend to have lower QBS-adapt index than pasture and forest soils as experimentally observed (Gardi et al. 2008). A high QBS-adapt index value was determined during the summer in ICL due to animal removal from this region and planting of soybean, improving the survival conditions for the springtails morphotypes. Lower QBS-adapt index values were determined in PA, indicating the influence of the climate changes, burned and types of land use systems (Baretta et al. 2005, Bartz et al. 2014b, Rosa et al. 2015). The burned processes of plants and forests as those that occurred in the southern plateau of the state of Santa Catarina increase the phosphorus concentrations and stimulate the seed germination (Bot \& Benites 2005). However, it can be harmful for the edaphic organism fauna since fire destroys most of the organic matter present on the soil surface which is an important food source and natural habitat for these organisms (DeBano et al. 1998, Malmström 2012).

The QBS-adapt index for eco-morphological groups in PA was higher for edaphic and hemiedaphic organisms compared to epigeic organisms in the different seasons. Some morphology and physiology results of the studied springtails morphotypes suggest that a more dynamic lifestyle strategy was adopted by the edaphic organisms whereas a more conservative lifestyle strategy was adopted by the edaphic organisms, preferring more stable and protective environments (Petersen 2002). As observed in this study and according to (Loring et al. 1981), the different land use systems affected significantly the springtails survival rates and their morphological characteristic in soils as studied elsewhere. However, the high QBS-adapt index values found for edaphic and hemiedaphic organisms pointed out for a non-polluted environment. For non-polluted environments, the springtails morphotypes were not affected by the variation of the physical and chemical soil properties or different land use systems (Hopkin 1997). 


\section{Conclusions}

Evaluating the springtails communities by monitoring their morphological characteristics was efficient for comparing the different land use systems. Native forests, eucalyptus plantations, pasture, integrated crop-livestock, and no-tillage systems were studied, describing the different land use systems by correlations with collembola communities and physical and chemical soil properties. Preserved land use systems were more appropriated and non-toxic for the determined collembola morphotypes. Significant correlations were determined between collembola morphotypes and physical and chemical soil properties during the winter, including biopores, calcium/ magnesium ratio, and total organic carbon content in soil, macroporosity, microporosity, and soil moisture. Significant correlations were also determined during the summer between springtails morphotypes and biopores, total organic carbon content, soil bulk density, $\mathrm{pH}$, and microporosity. The QBS-adapt index was an efficient and sensitive tool for the distinction of different land use systems for different seasons. Correlations among springtails morphotypes, QBS-adapt index, and physical and chemical soil properties generated practical and relevant informations for a fast evaluation of the soil quality. The diversity of the collembola communities could be also evaluated with low-cost and without taxonomy analysis.

\section{Acknowledgements}

The authors thank the Research and Innovation Support Foundation of Santa Catarina (FAPESC) (Process number 6.309/2011-6/FAPESC) and the National Council for Scientific and Technological Development (CNPq) (Process number 563251/2010-7/CNPq). Dilmar Baretta thanks the $\mathrm{CNPq}$ for his research productivity grant (Process number 307162/2015-0).

\section{Author Contributions}

Julia da Silva Machado: responsible for data collection, contribution to data analysis and interpretation, contribution to critical revision, adding intellectual content.

Luís Carlos Iuñes de Oliveira Filho: contribution to data analysis and interpretation, contribution to critical revision, adding intellectual content.

Julio Cesar Pires Santos and Alexandre Tadeu Paulino: contribution to critical revision, adding intellectual content.

Dilmar Baretta: responsible for sampling of springtails and for data collection, substantial contribution in the concept and design of the study, contribution to data analysis and interpretation, contribution to manuscript preparation, contribution to critical revision, adding intellectual content.

\section{Conflicts of interest}

The authors declare that they have no conflict of interest related to the publication of this manuscript.

\section{References}

Alvares, C.A., Stape, J.L., Sentelhas, P.C., Gonçalves, J.L.M. \& Sparovek, G. 2013. Köppen's climate classification map for Brazil. Meteorol. Zeitschrift. 22:711-728.
Bandyopadhyaya, I., Choudhuri, D.K. \& Ponge, J.-F. 2002. Effects of some physical factors and agricultural practices on Collembola in a multiple cropping programme in West Bengal (India). Eur. J. Soil Biol. 38:111-117.

Bardgett, R.D. \& Van Der Putten, W.H. 2014. Belowground biodiversity and ecosystem functioning. Nature. 515:505-511.

Baretta, D., Bartz, M.L.C., Fachini, I., Anselmi, R., Zortéa, T. \& Baretta, C.R.D.M. 2014. Soil fauna and its relation with environmental variables in soil management systems Fauna edáfica e sua relação com variáveis ambientais em sistemas de manejo do solo. Rev. Cienc. Agron. 45:871-879.

Baretta, D., Ferreira, C.S., Sousa, J.P. \& Cardoso, E.J.B.N. 2008. Colêmbolos (Hexapoda: Collembola) como bioindicadores de qualidade do solo em áreas com Araucaria angustifolia. Rev. Bras. Cienc. Solo. 32:2693-2699.

Baretta, D., Santos, J.C.P., Figueiredo, S.R. \& Klauberg-Filho O. 2005. Efeito do monocultivo de Pinus e da queima do campo nativo em atributos biológicos do solo no Planalto Sul Catarinense. Rev. Bras. Cienc. Solo. 29:715-724.

Bartz, M.L.C., Brown, G.G., Orso, R., Mafra, Á.L. \& Baretta D. 2014a. The influence of land use systems on soil and surface litter fauna in the western region of Santa Catarina. Rev. Cienc. Agron. 45:880-887.

Bartz, M.L.C., Brown, G.G., Rosa, M.G., Klauberg Filho, O., James, S.W., Decaëns, T. \& Baretta, D. 2014b. Earthworm richness in land-use systems in Santa Catarina, Brazil. Appl. Soil Ecol. 83:59-70.

Beylich, A., Oberholzer, H.-R., Schrader, S., Höper, H. \& Wilke, B.-M. 2010. Evaluation of soil compaction effects on soil biota and soil biological processes in soils. Soil Tillage Res. 109:133-143.

Bot, A. \& Benites, J. 2005. The importance of soil organic matter: Key to drought-resistant soil and sustained food production. Rome: FAO Soils Bulletin.

Cassagne, N., Gers, C. \& Gauquelin, T. 2003. Relationships between Collembola, soil chemistry and humus types in forest stands (France). Biol. Fertil. Soils 37:355-361.

Cavalieri, K.M.V., Silva, A.P., Tormena, C.A., Leão, T.P., Dexter, A.R. \& Håkansson, I. 2009. Long-term effects of no-tillage on dynamic soil physical properties in a Rhodic Ferrasol in Paraná, Brazil. Soil Tillage Res. 103:158-164.

Chagnon, M., Paré, D. \& Hébert, C. 2000. Relationships between soil chemistry, microbial biomass and the collembolan fauna of southern Québec sugar maple stand. Ecoscience.7:307-316.

Chagnon, M., Paré, D., Hébert, C. \& Camiré, C. 2001. Effects of experimental liming on collembolan communities and soil microbial biomass in a southern Quebec sugar maple (Acer saccharum Marsh.) stand. Appl. Soil Ecol. 17:81-90

Chang, L., Wu, H., Wu, D. \& Sun, X. 2013. Effect of tillage and farming management on Collembola in marsh soils. Appl. Soil Ecol. 64:112-117.

Clarke, K.R. 1993. Non-parametric multivariate analyses of changes in community structure. Austral Ecol. 18:117-143.

Culliney, T. 2013. Role of Arthropods in Maintaining Soil Fertility. Agriculture. 3:629-659.

DeBano, L.F., Neary, D.G., Ffolliott, P.F. 1998. Fire Effects on Ecosystems. New York: John Wiley \& Sons.

Eaton, R.J., Barbercheck, M., Buford, M. \& Smith, W. 2004. Effects of organic matter removal, soil compaction, and vegetation control on Collembolan populations. Pedobiologia. 48:121-128.

EMBRAPA - Empresa Brasileira de Pesquisa Agropecuária. 2011. Manual de métodos de análise de solo. 2 ed. Embrapa Solos, Rio de Janeiro.

EMBRAPA - Empresa Brasileira de Pesquisa Agropecuária. 2013. Sistema brasileiro de classificação de solos. 3 ed. Embrapa, Brasília.

Filser, J. 2002. The role of Collembola in carbon and nitrogen cycling in soil. Pedobiologia. 46:234-245.

Frazão, L.A., Píccolo, M.C., Feigl, B.J., Cerri, C.C. \& Cerri, C.E.P. 2008. Propriedades químicas de um Neossolo Quartzarênico sob diferentes sistemas de manejo no Cerrado mato-grossense. Pesq. Agropec. Bras. 43:641-648. 
Gardi, C., Menta, C. \& Leoni, A. 2008. Evaluation of the Environmental Impact of Agricultural Management Practices Using Soil Microarthropods. Fresenius Environ. Bull. 17:1165-1169.

Gardi, C., Tomaselli, M., Parisi, V., Petraglia, A. \& Santini, C. 2002. Soil quality indicators and biodiversity in northern Italian permanent grasslands. Eur. J. Soil Biol. 38:103-110.

Gisin, H. 1943. Ökologie und Lebensgemeinschaften der Collembolen im schweizerischen Exkursionsgebiet Basels. Rev Suisse Zool. 50:131-224.

Hammer, Ø., Harper, D.A.T. \& Ryan, P.D. 2001. PAST: Paleontological Statistics Software Package for Education and Data Analysis. Palaeontol. Electron. 4:1-9.

He, J., Li, H., Rasaily, R.G., Wang, Q., Cai, G., Su, Y., Qiao, X. \& Liu, L. 2011. Soil properties and crop yields after 11 years of no tillage farming in wheat-maize cropping system in North China Plain. Soil Tillage Res. 113:48-54.

Hopkin, S.P. 1997. Biology of the Springtails (Insecta: Collembola). Oxford: Oxford University Press.

Huerta, E. \& van der Wal, H. 2012. Soil macroinvertebrates' abundance and diversity in home gardens in Tabasco, Mexico, vary with soil texture, organic matter and vegetation cover. Eur. J. Soil Biol.50:68-75.

Ineson, P., Leonard, M.A. \& Anderson, J.M. 1982. Effect of collembolan grazing upon nitrogen and cation leaching from decomposing leaf crop residue. Soil Biol. Biochem. 14:601-605.

Jastrow, J.D., Miller, R.M. \& Boutton, T.W. 1996. Carbon Dynamics of Aggregate-Associated Organic Matter Estimated by Carbon-13 Natural Abundance. Soil Sci. Soc. Am. J. 60:801-807.

Jeffery, S., Gardi, C., Jones, A., Montanarella, L., Marmo, L., Miko, L., Ritz, K., Peres, G., Römbke, J. \& van der Putten, W.H. 2010. European Atlas of Soil Biodiversity. Luxembourg: Publications Office of the European Union.

Keesstra, S.D., Bouma, J., Wallinga, J., Tittonell, P., Smith, P., Cerdà, A., Montanarella, L., Quinton, J.N., Pachepsky, Y., van der Putten, W.H., Bardgett, R.D., Moolenaar, S., Mol, G., Jansen, B. \& Fresco, L.O. 2016. The significance of soils and soil science towards realization of the United Nations Sustainable Development Goals. SOIL. 2:111-128.

Keuls, M. 1952. The use of the ,studentized range" in connection with an analysis of variance. Euphytica. 1:112-122.

Larsen, T., Schjønning, P. \& Axelsen J. 2004. The impact of soil compaction on euedaphic Collembola. Appl. Soil Ecol. 26:273-281.

Lavelle, P., Decaëns, T., Aubert, M., Barot, S., Blouin, M., Bureau, F., Margerie, P., Mora, P. \& Rossi, J.-P. 2006. Soil invertebrates and ecosystem services. Eur. J. Soil Biol. 42:S3-S15.

Lima, A.C.R., Brussaard, L., Totola, M.R., Hoogmoed, W.B. \& Goede, R.G.M. 2013. A functional evaluation of three indicator sets for assessing soil quality. Appl. Soil Ecol. 64:194-200.

Loring, S.J., Snider, R.J. \& Robertson, L.S. 1981. The effects of three tillage practices on Collembola and Acarina populations. Pedobiologia. 22:172-184.

Madej, G., Barczyk, G. \& Gdawiec, M. 2011. Evaluation of soil biological quality index (QBS-ar): Its sensitivity and usefulness in the post-mining chronosequence - Preliminary research. Polish J. Environ. Stud. 20:13671372 .

Malmström, A. 2012. Life-history traits predict recovery patterns in Collembola species after fire: A 10 year study. Appl. Soil Ecol. 56:35-42.

Menta, C., Conti, F.D. \& Pinto, S. 2018a. Microarthropods biodiversity in natural, seminatural and cultivated soils-QBS-ar approach. Appl. Soil Ecol. 123:740-743.

Menta, C., Conti, F.D., Pinto, S. \& Bodini, A. 2018b. Soil Biological Quality index (QBS-ar): 15 years of application at global scale. Ecol. Indic. $85: 773-780$

Ogle, S.M., Breidt, F.J. \& Paustian, K. 2005. Agricultural management impacts on soil organic carbon storage under moist and dry climatic conditions of temperate and tropical regions. Biogeochemistry. 72:87-121.

Oliveira Filho, L.C.I. \& Baretta, D. 2016. Por que devemos nos importar com os colêmbolos edáficos? Sci. Agrar. 17:21-40.
Oliveira Filho, L.C.I., Klauberg Filho, O., Baretta, D., Tanaka, C.A.S. \& Sousa, J.P. 2016. Collembola Community Structure as a Tool to Assess Land Use Effects on Soil Quality. Rev. Bras. Cienc. Solo. 40:1-18.

Parisi, A. 2001. The biological soil quality, a method based on microarthropods (in Italy). Acta Nat. L'Ateneo Parm. 37:97-106.

Parisi, V., Menta, C., Gardi, C., Jacomini, C. \& Mozzanica, E. 2005. Microarthropod communities as a tool to assess soil quality and biodiversity: a new approach in Italy. Agric. Ecosyst. Environ. 105:323-333.

Paul, D., Nongmaithem, A. \& Jha, L.K. 2011. Collembolan Density and Diversity in a Forest and an Agroecosystem. Open J. Soil Sci. 1:54-60.

Paustian, K., Collins, H.P. \& Paul, E.A. 1997. Management controls on soil organic carbon. In Soil Org Matter Temp Agroecosystems. (E.A. Paul, E.T. Elliott, K. Paustian, C.V. Cole, eds.). CRC Press, Boca Raton, p. 15-49.

Petersen, H. 2002. General aspects of collembolan ecology at the turn of the millennium. Pedobiologia. 46:246-260.

Pflug, A. \& Wolters, V. 2002. Collembola Communities along a European Transect. Eur. J. Soil Biol. 38:301-304.

Pompeo, P.N., Oliveira Filho, L.C.I., Santos, M.A.B., Mafra, Á.L., Klauberg Filho, O. \& Baretta, D. 2017. Morphological Diversity of Coleoptera (Arthropoda: Insecta) in Agriculture and Forest Systems. Rev. Bras. Cienc. Solo. $41: \mathrm{e} 0160433$

Ponge, J.-F. 2000. Acidophilic Collembola: living fossils? Contrib. Biol. Lab. Kyoto Univ. 29:65-74.

Ponge, J.-F., Dubs, F., Gillet, S., Sousa, J.P. \& Lavelle, P. 2006. Decreased biodiversity in soil springtail communities: the importance of dispersal and land use history in heterogeneous landscapes. Soil Biol. Biochem. 38:1158-1161

Querner, P., Bruckner, A., Drapela, T., Moser, D., Zaller, J.G. \& Frank, T. 2013. Landscape and site effects on Collembola diversity and abundance in winter oilseed rape fields in eastern Austria. Agric. Ecosyst. Environ. 164:145-154.

Reis, F., Carvalho, F., Silva, P.M., Mendes, S., Santos, S.A.P \& Sousa, J.P. 2016. The use of a functional approach as surrogate of Collembola species richness in European perennial crops and forests. Ecol. Indic. 61:676-682.

Rieff, G.G., Natal-da-Luz, T., Sousa, J.P. \& Sá, E.L.S. 2014. Diversity of Springtails and Mites of a Native Forest In Southern Brazil: Relationship with the Indices of Temperature and Precipitation in the Native Environment. Int J. Emerg. Technol. Adv. Eng. 4:684-692.

Rosa, M.G., Klauberg Filho, O., Bartz, M.L.C., Mafra, Á.L., Sousa, J.P.F.A. \& Baretta, D. 2015. Macrofauna edáfica e atributos físicos e químicos em sistemas de uso do solo no planalto catarinense. Rev. Bras. Cienc. Solo. 39:1544-1553.

Roźen, A., Sobczyk, Ł., Liszka, K. \& Weiner, J. 2010. Soil faunal activity as measured by the bait-lamina test in monocultures of 14 tree species in the Siemianice common-garden experiment, Poland. Appl. Soil Ecol. 45:160-167.

Ruggiero, M.A., Gordon, D.P., Orrell, T.M., Bailly, N., Bourgoin, T., Brusca, R.C., Cavalier-Smith, T., Guiry, M.D. \& Kirk, P.M. 2015. Correction: A Higher Level Classification of All Living Organisms. PLoS One. 10:e 0130114

Santos, M.A.B., Oliveira Filho, L.C.I., Pompeo, P.N., Ortiz, D.C., Mafra, Á.L., Klauberg Filho, O. \& Baretta, D. 2018. Morphological diversity of springtails in land use systems. Rev. Bras. Cienc. Solo. 42:e0170277.

Sawahata, T. 2006. Hymenial area of agaric fruit bodies consumed by Collembola. Mycoscience.47:91-93.

Scheu, S. \& Folger, M. 2004. Single and mixed diets in Collembola: effects on reproduction and stable isotope fractionation. Funct. Ecol. 18:94-102.

Schröder, P. 2008. Mesofauna. In: Perspectives for Agroecosystem Management - balancing environmental and socioeconomic demands. (P. Schröder, J. Pfadenhauer, J.C. Munch, eds.). Elsevier, Amsterdam, p.293-306.

Silva, P.M., Carvalho, F., Dirilgen, T., Stone, D., Creamer, R., Bolger, T. \& Sousa, J.P. 2016. Traits of collembolan life-form indicate land use types and soil properties across an European transect. Appl. Soil Ecol. 97:69-77. 
Six, J., Elliott, E.T., Paustian, K. \& Doran, J.W. 1998. Aggregation and Soil Organic Matter Accumulation in Cultivated and Native Grassland Soils. Soil Sci. Soc. Am. J. 62:1367-1377.

Sousa, J.P., Bolger, T., Gama, M.M., Lukkari, T., Ponge, J.-F., Simón, C., Traser, G., Vanbergen, A.J., Brennan, A., Dubs, F., Ivitis, E., Keating, A., Stofer, S. \& Watt, A.D. 2006. Changes in Collembola richness and diversity along a gradient of land-use intensity: A pan European study. Pedobiologia. 50:147-156.

StatSoft I. 2004. STATISTICA (data analysis software system).

Tedesco, M.J., Gianello, C., Bissani, C.A. \& Volkweiss, S.J. 1995. Análises de Solo, Plantas e Outros Materiais. Universidade Federal do Rio Grande do Sul, Porto Alegre.

Ter Braak, C.J.F. \& Šmilauer, P. 2002. CANOCO Reference Manual and CanoDraw for Windows User's Guide: Software for Canonical Community Ordination (Version 4.5). Microcomputer Power, Wageningen.
Vandewalle, M., Bello, F., Berg, M.P., Bolger, T., Dolédec, S., Dubs, F., Feld, C.K., Harrington, R., Harrison, P.A., Lavorel, S., Silva, P.M., Moretti, M., Niemelä, J., Santos, P., Sattler, T., Sousa, J.P., Sykes, M.T., Vanbergen, A.J. \& Woodcock, B.A. 2010. Functional traits as indicators of biodiversity response to land use changes across ecosystems and organisms. Biodivers. Conserv. 19:2921-2947.

Verma, D., Yadav, R.K. \& Kumar, M. 2014. Effect of Ecological Factors on Population Density of Collembolan in Agra. J. Environ. Appl. Bioresearch. 2:25-28.

Winck, B.R., Sá, E.L.S., Rigotti, V.M. \& Chauvat, M. 2017. Relationship between land-use types and functional diversity of epigeic Collembola in Southern Brazil. Appl. Soil Ecol. 109:49-59.

WRB - World Reference Base for Soil Resources. 2014. A framework for international classification, correlation and communication. Food and Agriculture Organization of the United Nations. Rome: IUSS/ISRIC/FAO. (World Soil Resources Reports, 106).

Yang, X., Yang, Z., Warren, M.W. \& Chen, J. 2012. Mechanical fragmentation enhances the contribution of Collembola to leaf litter decomposition. Eur. J. Soil Biol. 53:23-31. 